\title{
Climate change and health: global issue, local responses
}

\author{
Anthony Capon a,b,d and Carlos Corvalana,b,c \\ a School of Public Health, University of Sydney, NSW, Australia \\ b Guest Editor, Public Health Research \& Practice, Issue 4, 2018 \\ c Environmental Health Branch, Health Protection NSW, NSW Health, Sydney, Australia \\ d Corresponding author: tony.capon@sydney.edu.au
}

\section{Article history}

Publication date: December 2018 Citation: Capon A, Corvalan C. Climate change and health: global issue, local responses. Public Health Res Pract. 2018;28(4):e2841823. https://doi. org/10.17061/phrp2841823
Climate change affects health directly through changing frequency, intensity and duration of extreme heat events, floods, droughts and storms, and indirectly through adverse changes in air pollution, the spread of disease vectors, food insecurity and undernutrition, displacement and mental ill health. ${ }^{1,2}$ According to the latest Intergovernmental Panel on Climate Change report ${ }^{3}$, the impacts and costs of a $1.5^{\circ} \mathrm{C}$ rise in global average temperatures since pre-industrial times will be far greater than previously expected. This report also found that without major cuts in carbon dioxide emissions, a $1.5^{\circ} \mathrm{C}$ rise in global average temperatures could be reached in as little as 12 years, and almost certainly within 20 years.

Internationally, climate change is now mainstream in health discourse. ${ }^{4}$ Research on health impacts of climate change suggests that health gains achieved over the past half century are being undermined by climate change. ${ }^{5}$ Given this, and the health co-benefits that accrue from actions for a sustainable economy, the 2015 Lancet Commission on Health and Climate Change concluded that tackling climate change could be the greatest global health opportunity of this century. ${ }^{2}$

In October 2016, the New South Wales (NSW) Government in Australia published the NSW Climate Change Policy Framework ${ }^{6}$, to respond to and mitigate the effects of climate change at a local level. Objectives of the framework include net-zero emissions by 2050 and for NSW to be more resilient to climate change. Within the framework, policy directions include reducing climate change impacts on health and wellbeing, and capturing co-benefits. One example of an initiative to arise from this framework is a multidisciplinary research group, the Human Health and Social Impacts Node, and some of the papers in this issue report findings of node research projects.

The papers in this issue address selected climate change and health issues in NSW, Australian and regional contexts. Hime and colleagues ${ }^{7}$ report the findings of a climate change and health policy investigation in NSW and conclude that building adaptive capacity and resilience, and mitigating climate change, creates opportunities to promote health. Boylan and colleagues ${ }^{8}$ propose a conceptual framework for climate change, health and wellbeing in NSW, based on the World Health Organization's Driving force, Pressure, State, Exposure, Effect and Action (DPSEEA) approach. Perkins-Kirkpatrick and Pitman ${ }^{9}$ provide a perspective on extreme events in the context of climate change, reporting the increase in heatwaves that is already occurring due to climate change, and uncertainty about how droughts and extreme rainfall 
events will change in the future. They argue that building resilience is the best way to safeguard communities.

Dr Colin Tukuitonga, who has served as Pacific Community Director-General since 2014, is interviewed ${ }^{10}$ by Public Health Research \& Practice Editor-in-Chief Don Nutbeam. Dr Tukuitonga is a general practitioner by training and has held senior public health roles in the New Zealand Government. He candidly explains the health risks from climate change in Pacific Island countries and the relevance of Australian climate change policy responses to health futures in these neighbouring countries.

Beggs ${ }^{11}$ reviews published research on the impacts of climate change on allergens and allergic diseases from an Australian perspective. He concludes that Australia's vulnerability to the adverse impacts of climate change on allergic diseases is compounded by the precarious nature of aeroallergen monitoring, reporting and forecasting in Australia. Charlesworth and colleagues ${ }^{12}$ reflect on environmental sustainability initiatives in NSW Health organisations. They note that, thus far, these efforts to reduce carbon emissions have been largely ineffective, and they present eight lessons for implementation. Prior and colleagues ${ }^{13}$ address built environment interventions for human and planetary health, and they highlight the utility of a health co-benefits framework in built environment practice.

These papers and current evidence point to the urgent need for stronger action on climate change to protect the health and wellbeing of current and future generations. Health offers a valuable perspective on climate change for three reasons. First, it makes the case for action on climate change more urgent because human health is already being adversely affected by extreme weather events that are being amplified in frequency, intensity and duration by climate change. Second, it makes the case for action on climate change more personal because there are compelling human stories to tell about loss of lives and livelihoods attributable to climate change. Third, there is a positive story to tell about the co-benefits for health from action on climate change, including the substantial contribution to reducing by two-thirds the 7 million annual deaths from air pollution by 2030. ${ }^{14}$

We hope you find these papers useful and that they inspire you to strengthen the focus on climate change in the work you do to protect and promote health.

\section{Peer review and provenance}

Internally peer reviewed, commissioned.

\section{Competing interests}

AC directs the Human Health and Social Impacts Node hosted by the University of Sydney with financial support from the NSW Office of Environment and Heritage and NSW Ministry of Health.

\section{Author contributions}

$\mathrm{AC}$ and $\mathrm{CC}$ contributed equally to writing and editing the article.

\section{References}

1. Butler CD. Climate change and global health. Wallingford, UK: CABI Publishing, 2014.

2. Watts N, Adger WN, Agnolucci P, Blackstock J, Byass P, Cai W, et al. Health and climate change: policy responses to protect public health. Lancet 2015;386: 1861-914.

3. Masson-Delmotte V, Zhai P, Pörtner HO, Roberts D, Skea J, Shukla PR, et al., eds. Global warming of $1.5^{\circ} \mathrm{C}$ : an IPCC special report on the impacts of global warming of $1.5^{\circ} \mathrm{C}$ above pre-industrial levels and related global greenhouse gas emission pathways, in the context of strengthening the global response to the threat of climate change, sustainable development, and efforts to eradicate poverty. Geneva: Intergovernmental Panel on Climate Change; 2018 [cited 2018 Nov 15]. Available from: www.ipcc.ch/report/sr15/

4. Patz JA, Thomson MC. Climate change and health: moving from theory to practice. PLoS Med 2018; 15(7):e1002628.

5. Smith KR, Woodward A, Campbell-Lendrum D, Chadee DD, Honda Y, Liu Q, et al. Human health: impacts, adaptation, and co-benefits. In Climate change 2014: impacts, adaptation, and vulnerability. Cambridge: Cambridge University Press, 2014. pp. 709-54.

6. Office of Environment and Heritage. NSW Climate Change Policy Framework. Sydney: State of NSW and Office of Environment and Heritage; 2016 [cited 2018 Nov 15]. Available from: www.environment.nsw.gov.au/-/ media/OEH/Corporate-Site/Documents/Climate-change/ nsw-climate-change-policy-framework-160618.pdf

7. Hime N, Vyas A, Lachireddy K, Wyett S, Scalley B, Corvalan C. Climate change, health and wellbeing: challenges and opportunities in NSW, Australia. Public Health Res Pract. 2018;28(4):e2841824.

8. Boylan S, Beyer K, Schlosberg D, Mortimer A, Hime N, Scalley B, et al. A conceptual framework for climate change, health and wellbeing in NSW, Australia. Public Health Res Pract. 2018;28(4):e2841826.

9. Perkins-Kirkpatrick S, Pitman A. Extreme events in the context of climate change. Public Health Res Pract. 2018;28(4):e2841825.

10. Tukuitonga $\mathrm{C}$. From crisis to action: responding to climate change in Pacific communities. Public Health Res Pract. 2018;28(4):e2841827.

11. Beggs PJ. Climate change and allergy in Australia: an innovative, high-income country, at potential risk. Public Health Res Pract. 2018;28(4):e2841828. 
12. Charlesworth KE, Stewart GJ, Sainsbury P. Addressing the carbon footprint of health organisations: eight lessons for implementation. Public Health Res Pract. 2018;28(4):e2841830.

13. Prior JH, Connon ILC, Mclntyre E, Adams J, Capon A, Kent $\mathrm{J}$, et al. Built environment interventions for human and planetary health: integrating health in climate change adaptation and mitigation. Public Health Res Pract. 2018;28(4):e2841831.
14. World Health Organization. Geneva: WHO; 2018. Clean air for health: Geneva action agenda; 2018 Nov 1 [cited 2018 Nov 15]. Available from: www.who.int/phe/news/ clean-air-for-health/en/

\section{Copyright: (c) (i) (-)}

(C) 2018 Capon and Corvalan. This article is licensed under the Creative Commons Attribution-NonCommercial-ShareAlike 4.0 International Licence, which allows others to redistribute, adapt and share this work non-commercially provided they attribute the work and any adapted version of it is distributed under the same Creative Commons licence terms. See: www.creativecommons.org/licenses/by-nc-sa/4.0/ 